\title{
Multinucleate host cells induced by Vittaforma corneae (Microsporidia)
}

\author{
Gordon J. Leitch ${ }^{1}$, Andrew P. Shaw ${ }^{1}$, Margaret Colden-Stanfield ${ }^{1}$, Mary Scanlon ${ }^{1}$ and Govinda S. Visvesvara ${ }^{2}$ \\ ${ }^{1}$ Department of Physiology, Morehouse School of Medicine, Atlanta, Georgia 30310, USA; \\ ${ }^{2}$ Division of Parasitic Diseases, Centers for Disease Control and Prevention, Atlanta, Georgia 30341-3724, USA
}

Key words: Vittaforma corneae, microsporidia, microtubule organizing centre, host-parasite interaction, multinucleate giant cell

\begin{abstract}
The microsporidium Vittaforma corneae (Shadduck, Meccoli, Davis et Font, 1990) develops within the target cell cytoplasm. In the present study, green monkey kidney (E6) cells infected at $30^{\circ} \mathrm{C}, 35^{\circ} \mathrm{C}$ or $37^{\circ} \mathrm{C}$ with $V$. corneae developed enlarged multinucleate structures of up to $200 \mu \mathrm{m}$ in any horizontal dimension made up either of a single cell or of multiple fused cells. A number of epithelial cell types (SW-480, HT-29, Caco-2 and HCT-8) were infected with $V$. corneae but did not induce the same highly organized structures, suggesting that for the structure to develop, the host cell must be capable of continued mitosis, and not be differentiated or be detaching from the surface matrix. Live cell imaging of infected E6 cells revealed large, multinucleate infected cells characterized by a central focus from which radiated parasite stages and host cell mitochondria. Immunocytochemistry identifying $\gamma$ and $\alpha$ tubulin suggested that a single centrally-located microtubule organizing centre governed the distribution of parasite stages and host cell organelles, with mitochondria and parasites being eventually transported towards the periphery of the structure. Whole cell patch clamp analysis of infected cells indicated an average five-fold increase in total membrane capacitance, consistent with an enlarged single cell. Scanning electron microscopy revealed cell-like protrusions around the periphery of the structure with the intervening space being made up of parasites and cell debris. Clearly in the case of $V$. corneae-infected E6 cells the parasite-host cell relationship involves subverting the host cell cytoskeleton and cell volume control, providing the parasite with the same protected niche as does a xenoma.
\end{abstract}

Microsporidia are ubiquitous intracellular parasites, originally thought of as protozoa and now considered closely related to fungi (van de Peer et al. 2000). With well over 1,000 species of microsporidia infecting species in every major animal phylum, it is not surprising that many divergent host-parasite relationships have evolved. As obligate intracellular parasites the microsporidia appear to have been able to reduce their genome size, simplify their organelle structures and reduce their biochemical pathways by subverting the host cell's physiology to provide the missing biochemical support for parasite development (Slamovits et al. 2004). As with other intracellular parasites, from viruses to protozoa (e.g., Halonen and Weidner 1994, Risco et al. 2002, Grieshaber et al. 2003), the microsporidia appear to modify host cell cytoskeleton, organelle arrangement, biochemistry and cell cycle to optimize the intracellular niche (Weidner et al. 1999, Scanlon et al. 2000, 2004). To date, compared with many other infectious agents, relatively little is known about how the microsporidia signal the host cells to affect these many changes that occur in host cell structure and function.

A xenoma is perhaps the most dramatic example of the extent of a microsporidia parasite's control over host cell structure and function (Lom and Nilsen 2003). In several species of hosts, microsporidia cause gross enlargement of the host cell. The single host nucleus becomes distorted while virtually all stages of the para- site can be observed developing free of identification by the host's immune system. Xenomas may get as large as several millimetres while still remaining a single cell with one, albeit significantly modified, nucleus. It is possible that the host cell nucleus divides with some microsporidia species (e.g. Faye et al. 1991). In their early stages xenomas provide the parasite with an environment free of host immune surveillance (Dyková et al. 1980). The present study was undertaken to describe the development of what was initially believed to be a xenoma-like structure seen in cultured green monkey (E6) cells infected with Vittaforma corneae (Shadduck, Meccoli, Davis et Font, 1990) (Davis et al. 1990, Shadduck et al. 1990, Silveira and Canning, 1995). Unlike a true xenoma, however, these structures are multinucleate with a pronounced central microtubule organizing centre (MTOC), and they lack the surrounding fibroblasts and other supporting structures usually seen in vivo.

\section{MATERIALS AND METHODS}

Parasite cultures. Vittaforma corneae (ATCC 50505) was carried in continuous culture in green monkey (Vero, E6)

This paper was presented at the NATO Advanced Research Workshop "Emergent Pathogens in the 21st Century: First United Workshop on Microsporidia from Invertebrate and Vertebrate Hosts", held in České Budějovice, Czech Republic, July 12-15, 2004. 
kidney cells (ATCC CRL-1586) maintained in Dulbecco's modified Eagle's medium supplemented with $10 \%$ foetal bovine serum, $10 \mu \mathrm{g} / \mathrm{ml}$ gentamicin and $0.5 \mu \mathrm{g} / \mathrm{ml}$ amphotericin B (Visvesvara et al. 1999). Cultures were maintained in 5\% $\mathrm{CO}_{2}$-air at $35^{\circ} \mathrm{C}$.

Infection of cultured cells. The following cell lines were cultured in the media that were recommended by the American Type Culture Collection, SW-480 (ATCC CCL-228), HT29 (ATCC HTB 38), HCT-8 (ATCC CCL 244) and Caco-2 (ATCC HTB-37). With the exception of the SW-480 cell line, all cultures were maintained in $5 \% \mathrm{CO}_{2}$-air at $35^{\circ} \mathrm{C}$ immediately before and after infection with purified $V$. corneae spores. The SW-480 cells were cultured in Liebovitz medium, supplemented with $10 \%$ foetal bovine serum, free of antibiotics, maintained in air at $35^{\circ} \mathrm{C}$. Two additional sets of experiments were performed, one at $30^{\circ} \mathrm{C}$, and one at $37^{\circ} \mathrm{C}$. Essentially the same structures were observed in cells cultured at all three temperatures. However, because the multinucleate infected cells described here were optimal at the two lower temperatures while cell growth was optimal at the two higher temperatures, only the cultures grown at $35^{\circ} \mathrm{C}$ are described in detail in the present communication.

Immunocytochemistry. In one experiment the distribution of intracellular parasite stages and host cell mitochondria was determined in viable $V$. corneae-infected E6 cells using the method described previously (Leitch et al. 1997, Scanlon et al. 2004). Briefly, host cells were loaded with the fluorescent probe, calcein, which in the host cell is found as an impermeable free acid incapable of passing the parasite plasma membrane, and MitoTracker-CMXRos which labels mitochondria. This method allows visualisation of the relationship of host cell mitochondria to negatively stained parasite stages, using confocal microscopy.

Infected and uninfected cells were cultured in 4- and 8-well chamber slides for immunofluorescent microscopy. Cells were fixed with methanol at $-20^{\circ} \mathrm{C}$ for $15 \mathrm{~min}$, rinsed 3 times with Tris buffered saline (TBS), then blocked with $2 \%$ bovine serum albumin (BSA) in TBS for $10 \mathrm{~min}$. In one group of experiments, cultures were double labeled for $\alpha$ tubulin and parasite stages, and in another group of experiments, for $\gamma$ tubulin and parasite stages. The primary antibodies used were mouse anti- $\alpha$ tubulin (Clone B-5-1-2, Sigma Chemical Co., St. Louis, MO) diluted 1:500 or mouse anti- $\gamma$ tubulin (Clone GTU-88, Sigma Chemical Co.,) diluted 1:500, together with rabbit anti- $V$. corneae (CDC), diluted $1: 500$ in $1 \%$ BSA in TBS. Samples were incubated for $1 \mathrm{~h}$ at $37^{\circ} \mathrm{C}$. After 3 rinses in TBS the secondary antibodies were applied. These were goat anti-mouse IgG-Biotin (Jackson ImmunoResearch, West Grove, PA) diluted 1:300, together with goat anti-rabbitAlexaFluor 594 (Molecular Probes, Eugene, OR) diluted $1: 750$ in $1 \%$ BSA in TBS. Samples were incubated for $1 \mathrm{~h}$ at $37^{\circ} \mathrm{C}$, then washed 3 times in TBS before exposure to Streptavidin-Oregon Green 488 (Molecular Probes), diluted 1:300, for $45 \mathrm{~min}$ at room temperature. In some experiments nuclei were visualised by labeling samples with DAPI, diluted $1: 1,000$, for $5 \mathrm{~min}$. Samples were then washed 3 times in TBS and mounted for fluorescent or confocal microscopic visualisation.

Cell capacitance measurements. To measure cell capacitance, as a reflection of cell size, in uninfected or infected E6 epithelial cells, we used the patch-clamp technique (Hamill et al. 1981) with an Axopatch 200A amplifier (Axon Instruments) and $4 \mathrm{M}$ borosilicate patch pipettes to gain access to the intracellular milieu using the whole-cell configuration. Under our experimental conditions we used a pipette solution containing (in mM): $150 \mathrm{KCl}, 0.1$ EGTA, $1 \mathrm{CaCl}_{2}$ (free $\left[\mathrm{Ca}^{2+}\right]$ $=26.5 \mathrm{nM}$ ) and 10 HEPES, $\mathrm{pH}$ to 7.2 with $\mathrm{KOH}$ and a standard bath solution containing (in $\mathrm{mM}$ ): $137 \mathrm{NaCl}, 5 \mathrm{KCl}, 2$ $\mathrm{CaCl}_{2}, 1 \mathrm{MgCl}_{2}, 5.5$ glucose, and 10 HEPES, pH to 7.3 with $\mathrm{NaOH}$ (Colden-Stanfield 2002). All experiments were performed at $22-24^{\circ} \mathrm{C}$ after correction of junction potentials. Total membrane capacitance $\left(\mathrm{C}_{\mathrm{m}}\right)$ was measured in the whole cell mode by integrating the capacity transient. $\mathrm{C}_{\mathrm{m}}$ was compared among the uninfected and infected groups using the unpaired Student's $t$-test.

\section{RESULTS}

The data presented here were obtained when E6 cells were infected with $V$. corneae and the cultures were carried at $35^{\circ} \mathrm{C}$. Figs. 1 and 2 , respectively, show confocal bright field images of an early and later stages of multinucleate cells seen when E6 cells were infected with $V$. corneae. A similar appearance was seen when the infected cells were cultured at $30^{\circ} \mathrm{C}$ or $37^{\circ} \mathrm{C}$, although the appearance of the cells was more organized and uniform at the lower temperature and less organized at the higher temperature. Typically the infected cell had a central focus with material, including parasite stages, radiating outwards. Multiple host cell nuclei were observed near the periphery of the cell. With time, the central region of the cell collapsed leaving a space, as shown in both multinucleate cells in Fig. 2 .

A total of five epithelial cell lines were infected with $V$. corneae. These were the undifferentiated E6 and SW480 cells, the poorly differentiated HT-29 cells and the highly polarized and differentiated Caco-2 and HCT-8 cells. HT-29 was poorly differentiated under the culture conditions used in the present study. Table 1 summarizes some of the properties of these cell lines. With the exception of the E6 cells these cell lines are all derived from human colonic carcinomas. Only the E6 cell gave rise to the large, highly organized, multinucleate infected cells described here. SW-480 cells are often multinucleate so that one would have predicted that the structure described here in infected E6 cells would have also occurred in the SW-480 cells. However, large multinucleate SW-480 cells were only very occasionally observed and these were seen with the same frequency in both infected and uninfected cultures and did not have the same level of organisation nor the large size seen in the infected E6 cells. Comparing the properties of the various cell lines, one would conclude from Table 1 that the organized multinucleate infected cell configuration was favoured in undifferentiated host cells that remained attached to the culture flask for an extended period and resisted apoptosis/necrosis.

We previously described an assay that could be used in viable microsporidia-infected cells in which calcein 

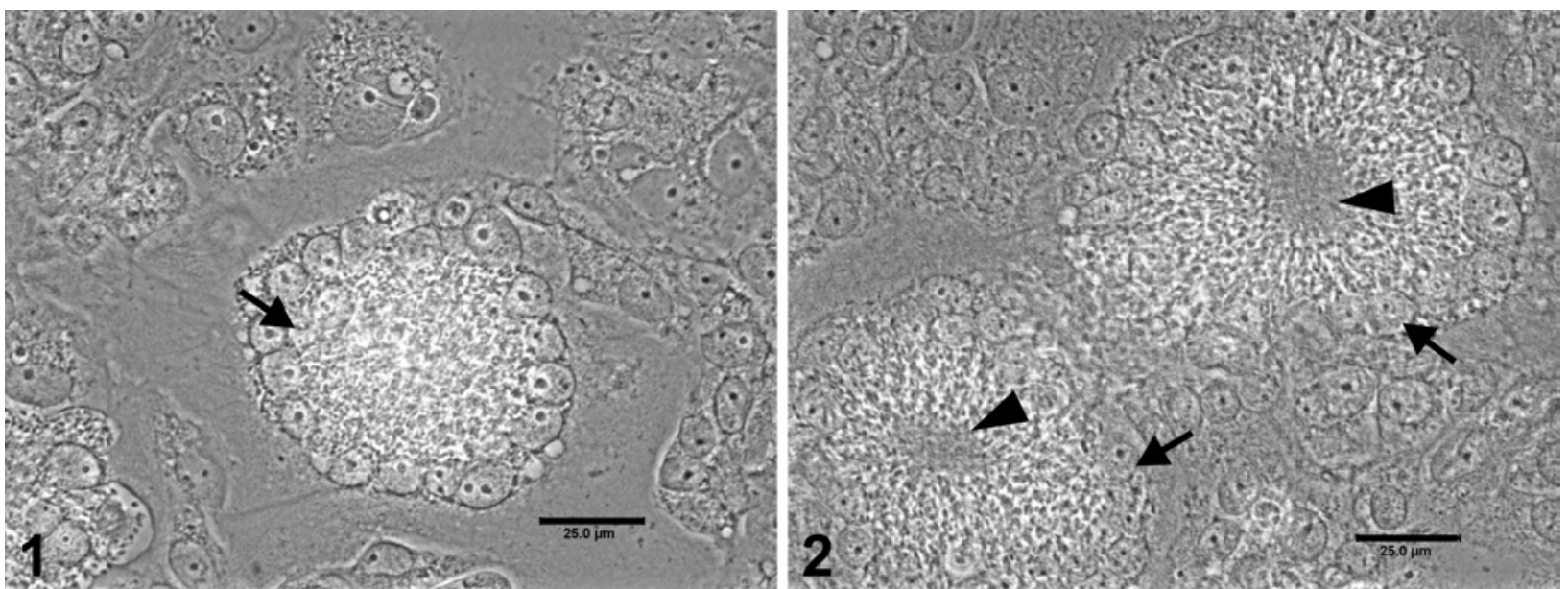

Figs. 1, 2. Confocal bright field images of Vittaforma corneae-infected multinucleate E6 cells. Fig. 1. Multinucleate cell (arrow), showing the peripheral location of the host cell nuclei. Fig. 2. Two multinucleate cells (arrows) showing collapsed centres to the structures (arrowheads). Scale bars $=25 \mu \mathrm{m}$.

Table 1. Summary of properties of cell lines tested for the development of highly structured multinucleate cells when infected with Vittaforma corneae.

\begin{tabular}{|l|c|c|c|c|c|}
\hline Property & E6 & SW-480 & HT-29 & Caco-2 & HCT-8 \\
\hline $\begin{array}{c}\text { V. corneae-induced } \\
\text { multinucleate cell }\end{array}$ & yes & no & no & no & no \\
\hline $\begin{array}{c}\text { Differentiated, } \\
\text { polarized monolayer }\end{array}$ & no & no & poorly & yes & yes \\
\hline $\begin{array}{c}\text { Uninfected cells remain } \\
\text { attached, little apoptosis }\end{array}$ & yes & moderate & moderate & yes & yes \\
\hline $\begin{array}{c}\text { Mononucleate/multinucleate } \\
\text { uninfected cell }\end{array}$ & mononucleate & both & mononucleate & mononucleate & mononucleate \\
\hline
\end{tabular}

was employed to negatively stain parasite stages and in which MitoTracker was used to probe host cell mitochondria (Scanlon et al. 2004). Fig. 3 illustrates the application of this method to study the $V$. corneae-induced multinucleate structure. In this and other images there appears to be a central focus, from which parasite stages and mitochondria radiate. In this confocal image the host cell nuclei are apparent central to an organelle-free cortex, and there are occasional concentrations of mitochondria (orange) distal to these nuclei. Parasite stages are negatively stained by this method and appear dark. The overall appearance suggests that there is some type of MTOC in the centre of the cell that organizes parasite stages, host cell organelles and nuclei down microtubules that radiate out from the centre. In this and similar images of infected cells the calcein distribution was uniform throughout the structure, with a cortex free of organelles and parasites, suggesting that while there was no membrane-bound intracellular partitioning there was a preferential location for the concentration of host cell organelles and parasites. The uniform calcein localisation with the multinucleate structure suggests it was a single cell rather than a cluster of infected cells.

Figs. 4 and 5 show confocal images of immunocytochemically double-labeled multinucleate cells produced after 14 days of infection with $V$. corneae. In these images $\alpha$ tubulin is labeled green and the microsporidia parasite stages are labeled red. In Fig. 4 the $\alpha$ tubulin staining suggests a single, central, large MTOC. Parasite stages (red) can be seen to radiate out from this MTOC. Typically in cells that have been infected for a longer period, the degree of organisation seen in Figs. 1-3 begins to be lost and multiple dense microtubule bundles develop. Fig. 5 shows a whole-cell composite confocal image of an infected cell in which such a dense tubulin bundle has developed. As the multinucleate cells increased in size, smaller MTOCs appeared near the periphery suggesting either a fusion of cells around the xenoma-like structure or resumption of cytokinesis in the areas of the most peripheral host cell nuclei.

To confirm that there was only a single MTOC in the most organized structures, examples of early multinucleate cells were double-labeled for $\gamma$ tubulin and parasite stages. Images of $\gamma$ tubulin should identify the location of the MTOC as it is via $\gamma$ tubulin that the microtubules are attached to the centrioles (Joshi 1994). Fig. 6 shows a fluorescent microscopic image of a $V$. corneae-infected, double-labeled multinucleate cell in which $\gamma$ tubulin appears green, parasite stages appear red and host cell nuclei and nuclei of adjacent unin- 
Table 2. Cell capacitance ( $\mathrm{pF})$ of uninfected E6 cells and Vittaforma corneae-infected multinucleate E6 cells.

\begin{tabular}{|l|c|c|}
\hline & Mean + SEM & Range \\
\hline Uninfected cells & $21.2 \pm 2.1$ & $12.3-32.6$ \\
\hline $\begin{array}{l}\text { V. corneae-infected } \\
\text { multinucleate cells }\end{array}$ & $97.3 \pm 12.1$ & $35.8-158.6$ \\
\hline Difference & $\mathrm{p}<0.01$ & \\
\hline
\end{tabular}

fected cells were stained with DAPI and appear blue. The punctuate $\gamma$ tubulin sites locate centrioles adjacent to individual E6 cell nuclei and in a cluster near the centre of the multinucleate cell. Figs. 4 and 6 are consistent with the interpretation that through most of the lifespan of these large multinucleate structures a single MTOC organizes the microtubules, determining the structural orientation of parasite stages and host cell organelles and nuclei.

To determine if these multinucleate cells were single cells as was suggested by the calcein-loaded cells, or were clustered or coalesced infected cells, the wholecell patch clamp technique (Hamill et al. 1981) was used to measure total membrane capacitance. Membrane capacitance is directly proportional to the plasma membrane surface area. Uninfected E6 cells were readily clamped. However, it was difficult to secure a good seal between the patch pipette and the infected multinucleate cells, suggesting that their surface was either significantly ruffled or covered with debris. Table 2 summarizes the results of some successful seals and subsequent whole-cell mode measurements in which the mean total membrane capacitance of infected cells was increased by an average of five-fold over the mean total membrane capacitance of uninfected cells. Transient values that were just in excess of $200 \mathrm{pF}$ were also obtained. Together with the uniform distribution of calcein, these data suggest that the smaller infected multinucleate structures were single cells. The capacitance values that were obtained, however, were lower than one would predict for the very large size of these multinucleate cells.

Scanning electron microscopic observations of the surface morphology of these multinucleate cells explained the difficulty in obtaining a seal in the patchclamp experiments. Typically, as the structures increased in size, their surface became covered with spores, polar tubes, debris, and presumably sporoplasm. However, frequently areas of smooth cell surface, the nature of which is still unknown, penetrated the surface debris (Fig. 7).

\section{DISCUSSION}

Intracellular parasites are well known for their ability to successfully subvert the structure and function of their host cells and thereby optimize their intracellular niche. The array of host-parasite relationships that have evolved has resulted in some very unique host cell structures, such as nurse cells produced by Trichinella (Despommier 1993) and xenomas produced by several microsporidia species (Lom and Nilsen 2003). The multinucleate structure described here has the gross appearance of a xenoma. However xenomas are usually mononucleate and often surrounded by fibroblasts and connective tissue.

The development of large cells filled with parasite stages requires significant modification of the host cell cytoskeleton. For example, the Encephalitozoon microsporidia develop within a parasitophorous vacuole and to accommodate the parasites, host cell microtubules reorganize around this vacuole (Leitch et al. 1999). In Toxoplasma gondii-infected cells the parasitophorous vacuole is stabilized by a sheath of host cell intermediate filaments (Halonen and Weidner 1994). In the present study it appears that the host cell microtubule cytoskeleton played a major role in organizing the Vittaforma corneae stages and supporting host cell organelles (Fig. 4). Having mitochondria and developing parasite stages organized by the same cytoskeletal elements helps ensure their proximity to one another and presumably optimizes host cell support of parasite development. This is similar to the situation seen in Encephalitozoon-infected cells where mitochondria are organized around the parasitophorous vacuole (e.g. Scanlon et al. 2004) and in Toxoplasma-infected cells where both endoplasmic reticulum and mitochondria are in intimate contact with the parasitophorous vacuole (Sinai et al. 1997). In the smaller and most highly organized multinucleate cells there was a clear cortex, devoid of parasites. This observation further suggests that the host cell microtubules dominate parasite distribution, rather than the microfilaments and associated proteins that generally constitute the cortex (Maupin and Pollard 1983).

Vittaforma corneae is a microsporidium that is rarely seen in humans. First named Nosema corneum by Davis and colleagues (1990) when found in a corneal stroma infection of an immunocompetent, HIV-negative patient, it was later renamed Vittaforma corneae (Silveira and Canning 1995). It was the first human microsporidium to be placed in culture (Shadduck et al. 1990). $V$. corneae causes a disseminated infection when administered intraperitoneally to immunodeficient mice (Silveira et al. 1993), and a Vittaforma-like microsporidium has recently been found in immunodeficient and immunocompetent Portuguese patients with diarrhoea (Sulaiman et al. 2003).

In the initial report describing the in vitro culturing of V. corneae (Shadduck et al. 1990), two epithelial cell lines were used, SIRC (ATCC 60) and MDCK (ATCC 34). While it was noted that host cell mitochondria clustered around the parasites that develop in the host cell cytoplasm, the cells became bloated with parasite stages and then detached. Multinucleate cells of the type 

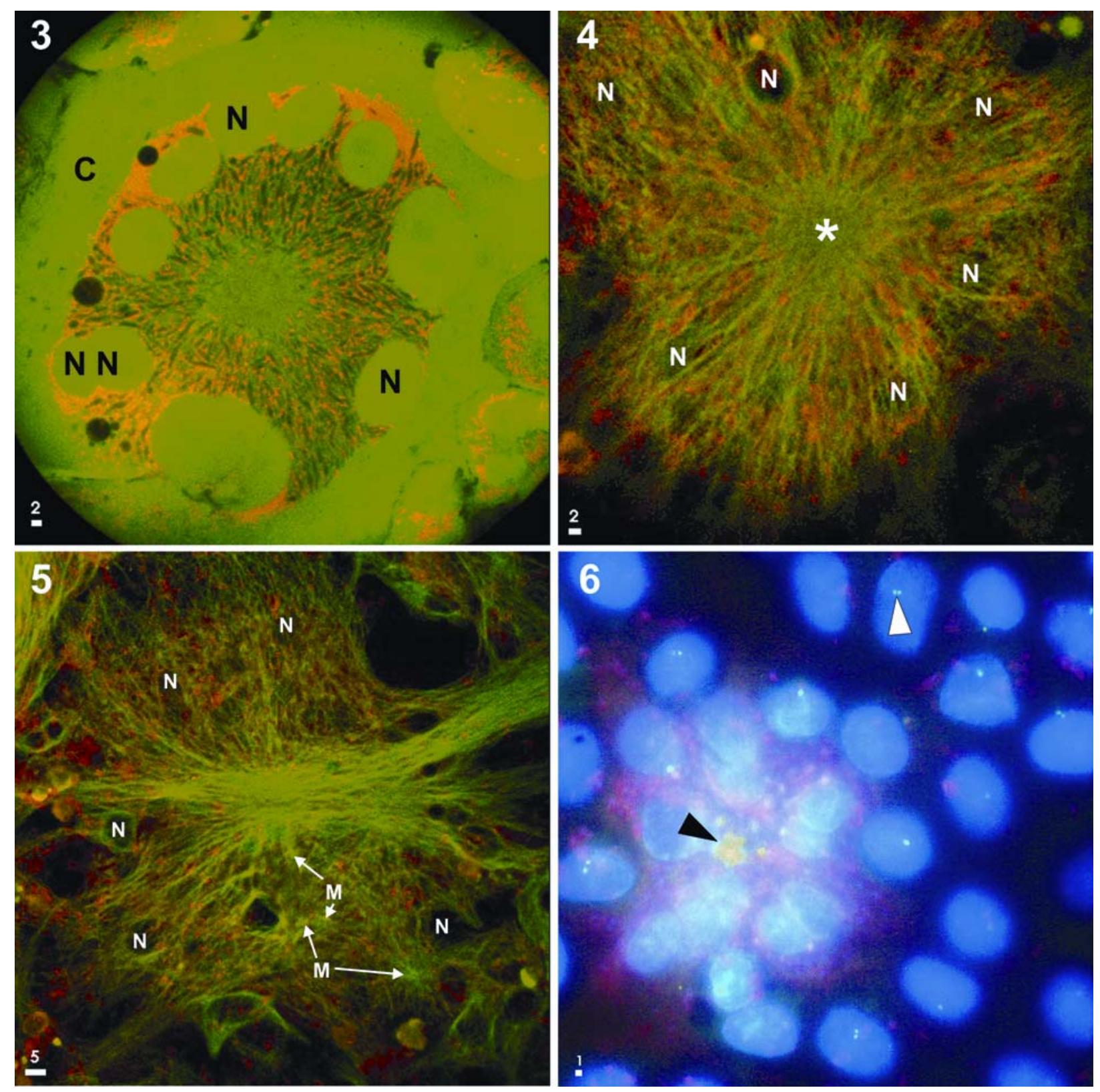

Figs. 3-6. Immunofluorescent images of Vittaforma corneae-infected multinucleate E6 cells illustrating the intracellular organisation of parasites and host cell microtubules, mitochondria and nuclei. Fig. 3. Confocal image of a calcein-loaded infected multinucleate E6 cell probed with MitoTracker showing the location of the host cell nuclei $(\mathrm{N})$ and the radiation of parasite stages (small dark central objects) and host mitochondria (orange) from a central site, all surrounded by an organelle-free cortex (C). Fig. 4. Confocal image of an infected multinucleate E6 cell probed for $\alpha$ tubulin (green) and parasite stages (red) demonstrating radiation of microtubules and parasite stages from a central microtubule organizing centre (MTOC) $(*)$. $\mathrm{N}-$ host cell nuclei. Fig. 5. Composite confocal image of a larger $V$. corneae-infected multinucleate E6 cell probed for $\alpha$ tubulin (green) and parasite stages (red) demonstrating large bands of microtubules. $\mathrm{N}$ - host cell nuclei. M - small MTOCs. Fig. 6. Immunofluorescent microscopic image of a $V$. corneae-infected multinucleate E6 cell probed for $\gamma$ tubulin (green) and parasite stages (red). Nuclei from the infected multinucleate cell and from surrounding mononucleate infected and uninfected cells were stained with DAPI (blue); $\gamma$ tubulin indicates the location of centrioles (white arrowhead) and the location of the multinucleate cell MTOC (black arrowhead). Scale bars: Figs. 3, $4=2 \mu \mathrm{m}$; Fig. $5=5 \mu \mathrm{m}$; Fig. $6=1 \mu \mathrm{m}$.

reported here were not described. SIRC is of rabbit corneal epithelium origin, but is biochemically more fibroblastic than it is epithelial (Niederkorn et al. 1990), while MDCK cells polarize and differentiate in culture. We have tested several cell lines for their ability to produce highly organized multicellular structures when 


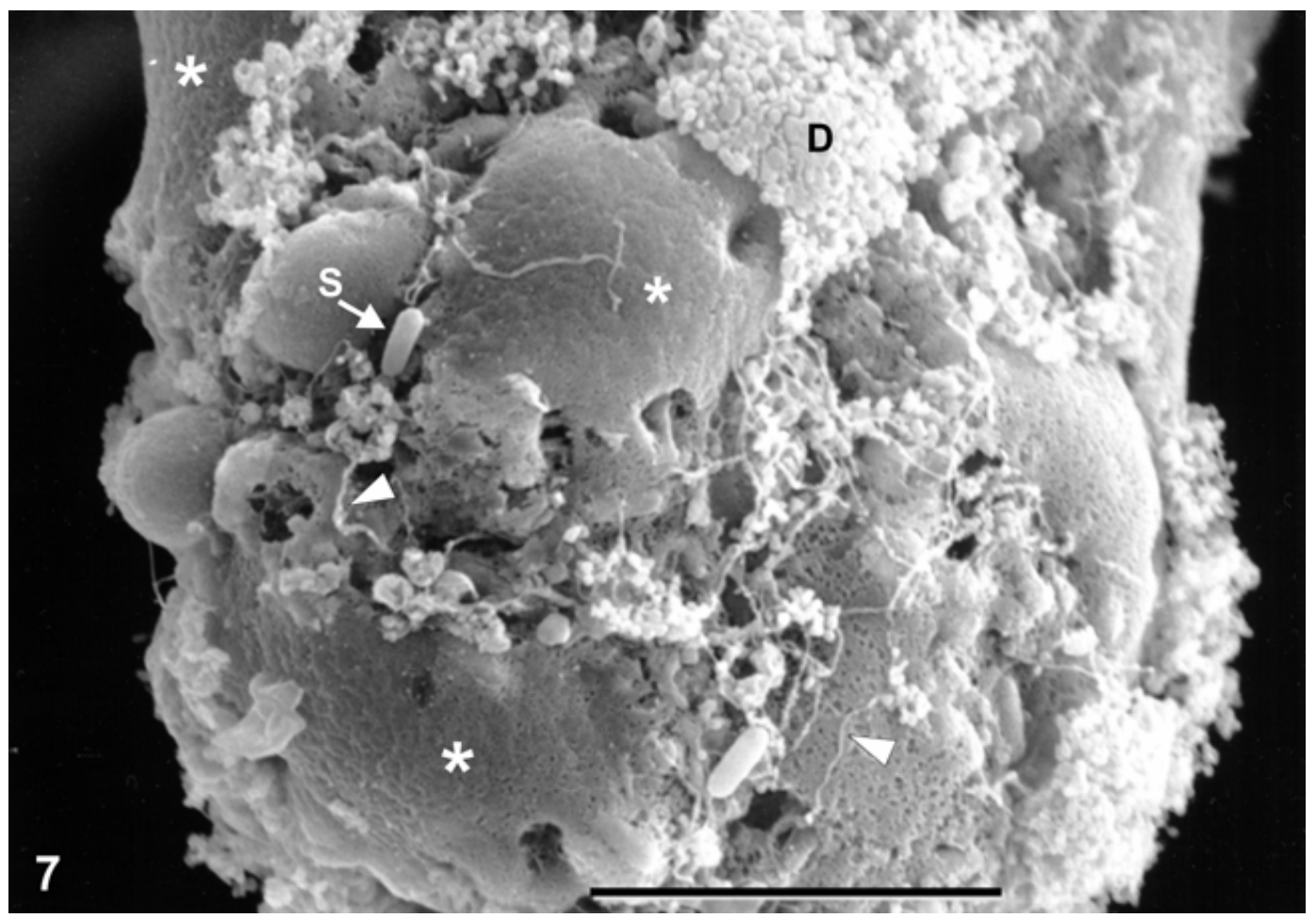

Fig. 7. Scanning electron micrograph of a section of a large $V$. corneae-infected multinucleate E6 cell structure. Parasite spores $(\mathrm{S})$, polar filaments (arrowheads), cell debris and presumed sporoplasm are visible (D), separating areas of cell surface $(*)$. Scale bar $=10 \mu \mathrm{m}$.

infected with $V$. corneae. As seen in Table 1, only E6 cells supported such a structure. E6 cells are nonpolarized, do not differentiate, and formed stable monolayers that supported infections for over 10 days. Of the cells that did not exhibit multinucleate structures when infected, Caco-2 and HCT-8 spontaneously differentiate and exhibit pronounced polarity, HT-29 is poorly differentiated under the culture conditions used here, and SW-480 is undifferentiated and lacks polarity (Chantret et al. 1988). SW-480 cells are frequently multinucleate. Nevertheless, these cells were unable to support the highly organized multinucleate structures described. SW-480 cells also differ from infected E6 cells in that they detached readily, as did the poorly differentiated HT-29 cells. The Caco- 2 cells and the HCT- 8 cells differentiate spontaneously and cell loss only occurred from the tips of villus structures. Thus it would appear that for the large multinucleate infected cells to develop, the host cell must be non-polarized, undifferentiated and be able to be maintained in a stable culture with a low rate of apoptosis/necrosis.

The early, well-organized multinucleate structures produced when $V$. corneae infects E6 cells (Figs. 1-3) suggested that nuclear division continued in the absence of cytokinesis. As the parasite load increased and the multinucleate cells continued to enlarge, cells appeared to have fused or cells and cell debris coalesced with the structure's surface (Figs. 5, 7). The early multinucleate structures were clearly single cells as determined by calcein loading experiments (Fig. 4) and membrane capacitance measurements (Table 2). While the infected cell membrane capacitance values were large enough to account for the early multinucleate structures being single cells, the values were not large enough to support the concept that the very large structures were single cells. However the difficulties encountered patching these larger structures may have skewed the results.

We were unable to determine if the multinucleate infected E6 cells were the result of continued nuclear division without cytokinesis, fusion of adjacent infected cells, or a combination of both. If the multinucleate cells were the result of continued mitosis in the absence of cytokinesis, one would expect to observe occasional mitotic spindles, which we did not. While there is only limited information available on the effects of microsporidial infection on the cell cycle, that which is available favours the inhibition of host cell mitosis (e.g. Scanlon et al. 2000). On the other hand, if cell fusion was the cause of the multinucleate cells, one would expect to have seen examples of partial fusion, which we did not observe. Multinucleate giant cells have long been known to result from monocyte cell fusion. This is an inflammatory response seen in many granulomas. In the Langerhans type of multinucleate giant cell the centrosomes of the fused cells locate centrally, giving rise to a central MTOC (Cain et al. 1981), similar to the 
cells reported here (Fig. 6). It is possible that the multinucleate infected cells we describe were a combination of this type of cell fusion, together with some mitosis without cytokinesis. The latter could be promoted by the loss of centrioles to a central MTOC. For example, Salisbury and colleagues (2002) used a centrin-2 "knockdown" method to show that with depletion of one or both centrioles the nuclei continued to divide for a limited time but cytokinesis was inhibited, resulting in multinucleate cells. After several nuclear divisions the cells died. If the multinucleate infected cells are indeed similar to inflammatory multinucleate giant cells and are the result of cell fusion, this would explain why the multinucleate SW-480 cells did not result in the high level of organisation of parasites and host cell nuclei described here. In cancer cell lines, such as SW-480, the multinucleate morphology is the result of continued mitosis and not fusion.

Whatever the cause of the multinucleate nature of these infected cells, it is clear that microtubules dominated the organisation of parasites and host cell organelles (Figs. 4-6). Centrioles from the multiple host cell nuclei coalesced (Fig. 6) to organize a single centrally located MTOC from which radiated microtubules (Fig.
4). Host cell mitochondria and parasite stages oriented themselves along the microtubules, and together with the host cell nuclei they were gradually moved outwards towards the plus end. This is one explanation for the more peripheral concentration of host cell nuclei, groups of mitochondria and occasionally clusters of parasite stages (Figs. 4 and 5). Another explanation is that the nuclei from fused infected cells, together with some of the cell's mitochondria and parasite stages remained at the periphery of the cell mass.

The present study describes the formation of large multinucleate cells when E6 cells are infected with $V$. corneae and in which single central MTOCs organize microtubules to orient parasites and supporting host cell organelles. Such a structure provides an environment that protects parasite development against the host immune response, much as is the case in a xenoma. Because of the limited number of clinical reports of $V$. corneae infections it has yet to be determined if this type of multinucleate structure is found in vivo or is unique to infected undifferentiated cultured epithelial cells.

Acknowledgements. Supported in part by US National Institutes of Health grants R21 DK064573-01A1 and RR03034.

\section{REFERENCES}

CAIN H., KRAUS B., FRINGES B., OSBORN M., WEBER K. 1981: Centrioles, microtubules and microfilaments in activated mononuclear and multinucleate macrophages from rat peritoneum: electron microscopic and immunofluorescence microscopic studies. J. Pathol. 133: 301-323.

CHANTRET I., BARBAT A., DUSSAULX E., BRATTAIN M.G., ZWEIBAUM A. 1988: Epithelial polarity, villin expression, and enterocytic differentiation of cultured human colon carcinoma cells: a survey of twenty cell lines. Cancer Res. 48: 1936-1942.

COLDEN-STANFIELD M. 2002: Clustering of very late antigen-4 integrins modulates $\mathrm{K}^{+}$currents to alter $\mathrm{Ca}^{2+}$ mediated monocyte function. Am. J. Physiol. (Cell Physiology): 283: C990-C1000.

DAVIS R.M., FONT R.L., KEISLER M.S., SHADDUCK J.A. 1990: Corneal microsporidiosis: a case report including ultrastructural observations. Ophthalmology 97: 953957.

DESPOMMIER D.D. 1993: Trichinella spiralis and the concept of niche. J. Parasitol. 79: 472-482.

DYKOVÁ I., LOM J., EGUSA S. 1980: Tissue reaction to Glugea plecoglossi infection in its natural host, Plecoglossus altivelis. Folia Parasitol. 27: 213-216.

FAYE N., TOGUEBAYE B.S., BOUIX G. 1991: Microfilum lutjani n.g. n.sp. (Protozoa Microsporida), a gill parasite of the golden African snapper Lutjanus fulgens (Valenciennes, 1830) (Teleost Lutjanidae): developmental cycle and ultrastructure. J. Protozool. 38: 30-40.

GRIESHABER S.S., GRIESHABER N.A., HACKSTADT T. 2003: Chlamydia trachomatis uses host cell dynein to traf- fic to the microtubule organizing center in a p50 dynamitin-independent process. J. Cell Sci. 116: 3793-3802.

HALONEN S.K., WEIDNER E. 1994: Overcoating of Toxoplasma parasitophorous vacuoles with host cell vimentin type intermediate filaments. J. Eukaryot. Microbiol. 41: 65-71.

HAMILL O.P., MARTY A., NEHER E., SAKMANN B., SIGWORTH F.J. 1981: Improved patch-clamp techniques for high-resolution current recording from cells and cellfree membrane patches. Pflugers Arch. 391: 85-100.

JOSHI H.C. 1994: Microtubule organizing centers and gamma-tubulin. Curr. Opin. Cell Biol. 6: 54-62.

LEITCH G.J., SCANLON M., SHAW A., VISVESVARA G.S. 1999: Modification of the cytoskeleton in Encephalitozoon-infected cells. J. Eukaryot. Microbiol. 46: 36S$37 \mathrm{~S}$.

LEITCH G.J., SCANLON M., SHAW A., VISVESVARA G.S., WALLACE S. 1997: Use of a fluorescent probe to assess the activities of candidate agents against intracellular forms of Encephalitozoon microsporidia. Antimicrob. Agents Chemother. 41: 337-344.

LOM J., NILSEN F. 2003: Fish microsporidia: fine structural diversity and phylogeny. Int. J. Parasitol. 33: 107-127.

MAUPIN P., POLLARD T.D. 1983: Improved preservation and staining of HeLa cell actin filaments, clathrin-coated membranes, and other cytoplasmic structures by tannic acid-glutaraldehyde-saponin fixation. J. Cell Biol. 96: 5162.

NIEDERKORN J.Y., MEYER D.R., UBELAKER J.E., MARTIN J.H. 1990: Ultrastructural and immunohistochemical characterization of the SIRC corneal cell line. In Vitro Cell Dev. Biol. 26: 923-930. 
RISCO C., RODRIGUEZ J.R., LOPEZ-IGLESIAS C., CARRASCOSA J.L. ESTEBAN M., RODRIGUEZ D. 2002: Endoplasmic reticulum-Golgi intermediate compartment membrane and vimentin filaments participate in vaccinia virus assembly. J. Virol. 76: 1839-1855.

SALISBURY J.L., SUINO K.M., BUSBY R., SPRINGETT M. 2002: Centrin-2 is required for centriole duplication in mammalian cells. Curr. Biol. 6: 1287-1292.

SCANLON M., LEITCH G.J., VISVESVARA G.S., SHAW A.P. 2004: Relationship between the host cell mitochondria and the parasitophorous vacuole in cells infected with Encephalitozoon microsporidia. J. Eukaryot. Microbiol. 51: 81-87.

SCANLON M., SHAW A.P., ZHOU C.J., VISVESVARA G.S., LEITCH G.J. 2000: Infection by microsporidia disrupts the host cell cycle. J. Eukaryot. Microbiol. 47: 525531.

SHADDUCK J.A., MECCOLI R.A., DAVIS R., FONT R.L. 1990: Isolation of a microsporidian from a human patient. J. Infect. Dis. 162: 773-776.

SILVEIRA H., CANNING E.U. 1995: Vittaforma corneae n. comb. for the human microsporidium Nosema corneum Shadduck, Meccoli, Davis and Font, 1990, based on its ultrastructure in the liver of experimentally infected athymic mice. J. Eukaryot. Microbiol. 42: 158-165.

SILVEIRA H., CANNING E.U., SHADDUCK J.A. 1993: Experimental infection of athymic mice with the human microsporidian Nosema corneum. Parasitology 107: 489496.
SINAI A.P., WEBSTER P., JOINER K.A. 1997: Association of host cell endoplasmic reticulum and mitochondria with the Toxoplasma gondii parasitophorous vacuole membrane - a high affinity interaction. J. Cell Sci. 110: $2117-$ 2128.

SLAMOVITS C.H., FAST N.M., LAW J.S., KEELING P.J. 2004: Genome compaction and stability in microsporidian intracellular parasites. Curr. Biol. 25: 891-896.

SULAIMAN I.M., MATOS O., LOBO M.L., XIAO L. 2003: Identification of a new microsporidian parasite related to Vittaforma corneae in HIV-positive and HIV-negative patients from Portugal. J. Eukaryot. Microbiol. 50 (Suppl.): 586-590.

VAN DE PEER Y., BEN ALI A., MEYER A. 2000: Microsporidia: accumulating molecular evidence that a group of amitochondriate and suspectedly primitive eukaryotes are just curious fungi. Gene 246: 1-8.

VISVESVARA G.S., MOURA H., LEITCH G.J., SCHWARTZ D.A. 1999: Culture and propagation of microsporidia. In: M. Whittner and L.M. Weiss (Eds.), The Microsporidia and Microsporidiosis. ASM Press, Washington, D.C., pp. 363-392.

WEIDNER E., FINDLEY A.M., DOLGIKH V., SOKOLOVA J. 1999: Microsporidian biochemistry and physiology. In: M. Whittner and L.M. Weiss (Eds.), The Microsporidia and Microsporidiosis. ASM Press, Washington, D.C., pp. 172-195. 